\title{
ВПЛИВ ЧАСТОТИ СЕРЦЕВИХ СКОРОЧЕНЬ НА ТОЛЕРАНТНІСТЬ ДО ФІЗИЧНИХ НАВАНТАЖЕНЬ У ПАЦІЄНТІВ ІЗ ПОСТІЙНОЮ ФОРМОЮ ФІБРИЛЯЦІї ПЕРЕДСЕРДЬ НЕКЛАПАННОГО ПОХОДЖЕННЯ
}

\author{
๑О. С. Сичов' , П. Б. Романюк' , О. В. Срібна', В. Г. Гур'янов² \\ 1 Державна установа «Національний науковий центр «Інститут кардіології імені академіка \\ М. Д. Стражеска» Національної академії медичних наук України» \\ ${ }^{2}$ Національний медичний університет імені О. О. Богомольця
}

РЕЗЮМЕ. Мета дослідження - оцінити динамічні зміни толерантності до фізичних навантажень у пацієнтів із постійною формою фібриляції передсердь неклапанного походження на фоні застосування $\beta$-адреноблокаторів (ББ), визначити критичне значення ЧСС як предиктор негативної динаміки функціонального стану пацієнтів при 6-місячному спостереженні, виявити перевагу однієї із стратегій контролю ЧСС.

Матеріал і методи. У дослідження послідовно включено 30 пацієнтів. Тривалість спостереження становила $(238,3 \pm 17,0)$ днів, дизайн передбачав 3 візити. Титрування дози ББ проводилось $(67,7 \pm 10,3)$ днів (інтервал між 1 та 2 візитами). Прийом максимальної або максимально переносимої дози ББ тривав $(170,6 \pm 17,7)$ днів (інтервал між 2 та 3 візитами). Парні навантажувальні проби - тредміл-тест (ТT) та тест 6-хвилинної ходьби (6XTX) проводились під час другого та заключного візитів.

Результати. Протягом 6-місячного спостереження у обстежуваної групи пацієнтів значимо зросли САТ на фоні субмаксимального ФН, інотропний резерв та резерв подвійного добутку (ПД), а також зменшився індекс ПД. Здійснений кореляційний аналіз виявив зв'язок індексу ПД із показником середньодобової чСС за даними 24-годинного ХМ ЕКГ. За умови досягнення жорсткого контролю чСС через 6 місяців значимо зменшилась відстань, пройдена пацієнтами при 6ХТХ. При зіставленні обох стратегій жорсткий контроль показав значиму перевагу щодо зниження ЧСС спокою, ЧСС на фоні субмаксимального ФН (2 і 3 візити), ПД спокою, індексу ПД, а також підвищення досягнутого хронотропного резерву (2 візит).

Висновки. Через 6 місяців при застосуванні ББ у хворих на ПФФП неклапанного походження відзначається покращення толерантності до ФН. Предиктором її зниження $\epsilon$ середньодобова ЧСС 90,5 уд/хв, зафіксована під час ХМ ЕКГ. Жорсткий контроль ЧСС має перевагу перед м'яким щодо покращення функціонального стану пацієнтів та їх прогнозу.

КЛючОВІ СлОВА: постійна форма фібриляції передсердь; контроль частоти серцевих скорочень; толерантність до фізичних навантажень; тредміл-тест; тест 6-хвилинної ходьби.

Вступ. Поширеність фібриляції передсердь (ФП) у загальній популяції протягом останнього десятиліття збільшилась удвічі і, за даними епідеміологічних досліджень, становить 2 \%. Розповсюдженість ФП змінюється із віком: у осіб молодше 49 років - 0,12-0,16 \%; у людей віком 6070 років $-3,70-4,20 \%$, а у осіб у віці 80 років або старше - 10-17 \% [1]. Постійна форма фібриляції передсердь (ПФФП) спостерігається у половини хворих на ФП [1-3]. Частота серцевих скорочень (ЧСС) у спокої >80 уд/хв фіксується майже у $50 \%$ пацієнтів із ПФФП $[2,3]$. Адекватний контроль ЧСС пов'язаний зі зниженням проявів симптомів аритмії та серцевої недостатності (CH) i $\epsilon$ важливою мішенню для поліпшення терапії хворих на ПФФП [2]. Відомо, що серед пацієнтів із ПФФП зафіксована Ј-подібна залежність між ЧСС і смертністю [4]. Цільові показники ЧСС, як у спокої, так і при фізичних навантаженнях $(Ф Н)$, у хворих на ПФФП залишаються невстановленими величинами $[5,6]$. Європейське товариство кардіологів не висловило єдиної думки щодо даної проблеми у останніх рекомендаціях 2016 р. Так, згідно з настановою по лікуванню ФП терапію пацієнтів із ПФФП варто розпочинати із ЧСС спокою <110 уд/хв, то6то "м'якого" контролю, незалежно від показника систолічної функції лівого шлуночка, якщо симптоми не вимагають більш жорсткого контролю [5]. У настанові по терапії хворих із СН зафіксовано інші показники, а саме - ЧСС 70-100 уд/хв, які, на думку експертів, можуть бути більш прийнятними [6]. Варто звернути увагу, що на можливість контролювати ЧСС у стані спокою до 110 уд/хв вказують результати лише одного мета-аналізу $[7,8]$. Слід також зазначити, що існуючі рекомендації сформовані на основі результатів, отриманих під час клінічного дослідження RACE II, у якому ЧСС спокою оцінювалась за допомогою лише електрокардіограми (ЕКГ), а 24-годинний холтерівський моніторинг ЕКГ (ХМ ЕКГ) та навантажувальна проба (НП) проводились лише пацієнтам, щодо яких застосовувалась стратегія жорсткого контролю [8]. Визначено, що ХМ ЕКГ та 6-хвилинний тест ходьби (6ХTX, 6МWT) можуть використовуватись у якості додаткових методів для більш точного прогнозування якості життя пацієнтів із ПФФП [9]. Існують дані, що пацієнти із ПФФП мають кращу переносимість ФН при ЧСС спокою в 
Огляди літератури, оригінальні дослідження, погляд на проблему

межах 80-100 уд/хв [10]. Оптимальна ЧСС при ФН у хворих із СН та ПФФП не з'ясована, але може становити <110 уд/хв під час легкого навантаження [11]. Цільові показники контролю чСС при ПФФП у пацієнтів із СН із збереженою фракцією викиду лівого шлуночка (ЗФВ ЛШ), у тому числі на фоні ФН, ще не встановлено [12].

ЧСС при ПФФП безпосередньо пов'язана з потребою організму у кисні [13]. Основним завданням лікування таких хворих $\epsilon$ контроль ЧСС у стані спокою і під час ФН [14]. Зниження ЧСС спокою у пацієнтів із ПФФП асоційоване із покращеною гемодинамічною реакцією організму під час ФН [15]. Вплив терапії на ЧСС під час ФН та її клінічні прояви для лікування пацієнтів із ПФФП залишаються невідомими. У пацієнтів із ПФФП під час жорсткого контролю важлива не тільки ЧСС спокою, але й максимальна ЧСС на ФН. Взаємодія між ними ніколи раніше не досліджувалась [16]. $\beta$-адреноблокатори (ББ), як правило, використовуються для контролю ЧСС у хворих із ПФФП, у тому числі під час $Ф$. Проте мало відомо про їх вплив на толерантність до ФН у цих пацієнтів [14]. Ефективний контроль ЧСС у спокої не обов'язково свідчить про адекватний контроль ЧСС під час навантаження, тому НП дозволяє полегшити титрування ББ для досягнення цих завдань [17]. Критерієм ефективності терапії пацієнтів із ПФФП повинна бути ретельна оцінка впливу препаратів для контролю ЧСС на якість життя і толерантність до ФН, а не першочергове зниження частоти скорочення шлуночків [18].

Мета дослідження - оцінити динамічні зміни толерантності до фізичних навантажень у пацієнтів із постійною формою фібриляції передсердь неклапанного походження на фоні застосування $\beta$-адреноблокаторів, визначити критичне значення ЧСС, як предиктор негативної динаміки функціонального стану пацієнтів при 6-місячному спостереженні, виявити перевагу однієї із стратегій контролю чСС.

Матеріал і методи дослідження. У дослідження послідовно включено 30 пацієнтів із
ПФФП неклапанного походження. Середній вік хворих складав $(56,9 \pm 1,4)$ років, жінок було 9 (30\%), а чоловіків - 21 (70\%). Задокументований анамнез ФП становив у середньому $(9,5 \pm 1,0)$ років, а власне ПФФП - $(7,5 \pm 0,9)$ років. ПФФП у хворих існувала на фоні міокардіофіброзу у 4 (13,3\%) та ішемічної хвороби серця - відповідно у 26 (86,7 \%) пацієнтів. У 4 (13,3 \%) пацієнтів фіксувалась стабільна стенокардія напруги, постінфарктний кардіосклероз в анамнезі у $3(10,0 \%)$, стентування в анамнезі у 1 (3,3\%). Гіпертонічна хвороба зустрічалась у 27 (90,0\%) людей, із них I стадія у 1 (3,3\%), ІІ стадія у $1(3,3 \%)$, a III - у 25 (83,3 \%). у 18 (60,0 \%) хворих задокументована гіпертонічна хвороба II ступеня, а у $9(90,0 \%)$ - III. За шкалою ризику виникнення серцево-судинних подій SCORE пацієнти розподілялись наступним чином: дуже високий ризик зафіксовано у 16 (53,3\%), високий - у 2 (6,7\%), помірний - у 11 (36,7\%), низький - у 5 (3,3\%). Супутня серцева недостатність I ст. задокументована у 5 (16,7 \%) хворих, у решти 25 (83,3\%) - II А ст. У $2(6,7 \%)$ пацієнтів зафіксована систолічна дисфункція лівого шлуночка за даними ЕхоКГ. Станом на I візит у 8 (26,7 \%) хворих мав місце I функціональний клас за шкалою NYHA, у 14 (46,7 \%) - II ФК, у 4 (26,6 \%) - III ФК. Цукровий діабет 2 типу зафіксовано у 7 (23,3 \%) пацієнтів, гостре порушення мозкового кровообігу в анамнезі у $3(10,0 \%)$, хронічне обструктивне захворювання легень (ХОЗЛ) у 1 (3,3 \%). Ризик тромбоутворення за шкалою CHA2DS2-VASC 1 бал зафіксовано у 10 (30,0 \%) хворих, 2 - у 15 (50,0 \%), 3 - у 4 (13,4 \%), 4 - у 1 (3,3\%). Ризик кровотечі за шкалою HAS-BLED 1 бал виявлено у 28 (93,3 \%) пацієнтів, а 2 - відповідно у 2 (6,7 \%). Індекс маси тіла у обстежених хворих на момент I візиту становив $33,3 \pm 1,1 \mathrm{kr} / \mathrm{M}^{2}$, тобто мало місце ожиріння I ступеня. Станом на II візит у 9 (30 \% \%) пацієнтів досягнуто жорсткого контролю ЧСС, у 21 (70,0\%) - м'якого, а на III відповідно -у 15 (50 \%) та 15 (50\%). Для контролю ЧСС застосовували наступні препарати: бісопролол у 27 (96,7 \%) хворих, карведилол у 3 (3,3 \%), дигоксин у 6 $(20,0 \%)$, їх дозування наведено у таблиці 1.

Таблиця 1. Характеристика терапії контролю чсС

\begin{tabular}{|l|c|c|c|c|}
\hline \multirow{2}{*}{\multicolumn{1}{|c|}{ Препарат, мг }} & \multicolumn{4}{|c|}{ Середнє значення, $\bar{X} \pm \mathrm{m}(\mathrm{n}=30)$} \\
\cline { 2 - 5 } & І візит & II візит & III візит & $\mathrm{P}$ \\
\hline Бісопролол & $6,85 \pm 0,45$ & $7,5 \pm 0,46$ & $7,5 \pm 0,46$ & 0,06 \\
\hline Карведилол & $28,13 \pm 11,80$ & $32,3 \pm 12,00$ & $32,3 \pm 12,00$ & 0,37 \\
\hline Дигоксин & $0,29 \pm 0,04$ & $0,24 \pm 0,06$ & $0,24 \pm 0,06$ & 0,37 \\
\hline
\end{tabular}

Загалом тривалість даного дослідження складала $(238,3 \pm 17,0)$ днів, а дизайн передбачав 3 візити. Титрування дози ББ тривало $(67,7 \pm 10,3)$ днів, саме на стільки були розведені у часі перший та другий візити. $(170,6 \pm 17,7)$ днів тривав прийом максимальної або максимально переносимої дози ББ, тобто інтервал між другим та заключним візитами. Досліджувані дані відображені у таблиці 2. 
Огляди літератури, оригінальні дослідження, погляд на проблему

Таблиця 2. Дизайн проспективного дослідження

\begin{tabular}{|l|c|c|c|}
\hline \multicolumn{1}{|c|}{ Показник } & І візит & II візит & III візит \\
\hline Демографічні та загальноклінічні дані & + & + & + \\
\hline \multicolumn{2}{|c|}{ Інструментальні методи обстеження } \\
\hline 24-годинний ХМ ЕКГ & + & + & + \\
\hline Тредміл-тест & & + & + \\
\hline 6-хвилинний тест ходьби & & + & + \\
\hline
\end{tabular}

ХМ ЕКГ проводився із використанням реєстраторів «03250В» («Сольвейг», Україна) для оцінки середньодобової, максимальної та мінімальної добової, середньої ЧСС в активний та пасивний періоди (в уд/хв і мс), циркадного індексу, кількості та тривалості пауз (більше 2000 мс).

Для оцінки толерантності до ФН пацієнтам проводилась НП на тредмілі «VALIANT» (Lode BV, Нідерланди) із електрокардіографом «СагdioPC Professional» (Innomed Medical inc., Угорщина) згідно з уніфікованими протоколами Bruce та Bruce mod до досягнення субмаксимальної чСС (85 \% від очікуваної максимальної чСС), розрахованої згідно статі, віку та маси тіла обстежуваного [19]. Проводилось вимірювання ЧСС в уд/хв, систолічного (САТ) та діастолічного (ДАТ) артеріального тиску в мм Нg у спокої та на піку ФН. Очікувану максимальну чСС (оч $\max$ ЧСС, уд/хв) за віком визначали за формулою: оч $\max$ ЧСC $=(208-0,7 \times$ вік $)$ для чоловіків та оч $\max$ ЧСC=(206-0,88×вік) для жінок $[19,20]$. Формула, що використовувалась для розрахунку очікуваного максимального споживання кисню (оч $\mathrm{VO}_{2 \max }=$ оч $\max _{\mathrm{VO}_{2}}$ (мл/кг/хв)): оч $\max \mathrm{VO}_{2}=(3,542+(-0,014 \times$ вік $)+(0,015 \times$ маса тіла $)+$ $(-0,011 \times$ чСС спокою))×1000/маса тіла [21]. Розрахунковий показник метаболічного еквівалента (MET_N) визначали за формулою MET_N=VO ${ }_{2 \max } / 3,5$ [22]. Толерантність до фізичних навантажень визначали шляхом співвідношення показників досягнутого і розрахункового метаболічних еквівалентів (MET/MET_N). Показник менше 0,6 вказує на дуже низьку (ТH=4), 0,6-0,75 - низьку (ТH=3), 0,75-0,9 - середню (ТН=2), понад 0,9 - високу працездатність (TH=1) [17]. Перерахунки метаболічних еквівалентів у Вати (Вт) та розрахункових метаболічних еквівалентів у розрахункові Вати (Вт_N) проводили за формулою: Вт=(маса тілахМЕТ-90)/3,44 та Вт_N=(маса тілахМЕT_N-90)/3,44 відповідно [17]. Визначення виконаної роботи протягом фізичного навантаження у кілоджоулях (кДж) та розрахункової виконаної роботи (кДж_N) проводили за формулою: кДж=Втхи нав-ня (час, протягом якого виконувалось фізичне навантаження у c) та кДж_N=Bт_N×t нав-ня відповідно [23]. Хронотропний резерв міокарда (XP) оцінювався за формулою: дос ХР=(дос $\max$ ЧСС-ЧСС спок)/ чСС спок та оч XР=(оч $\max$ ЧСС-ЧСС спок)/ЧСС спок, тобто отримували співвідношення різниці ЧСС на піку навантаження і ЧСС в спокої до ЧСС в спокої $[14,19]$. Хронотропна некомпетентність (ХН) визначалась при досягнутому ХР $\leq 62 \%[19,24]$. Визначався також досягнутий інотропний резерв міокарда, що становить різницю між досягнутим САТ на піку ФН і САТ у спокої: дос IP=max CАТ-САТ спок. Оцінка подвійного добутку (ПД) проводилась за формулою: спок ПД=ЧСС спок×САТ спок/100 і відповідно max ПД=дос $\max$ ЧСС × $\max$ CАТ/100 [17, 23]. Визначення резерву подвійного добутку (резерв ПД) здійснювалось за формулою: резерв ПД= max ПД-спок ПД [25]. Також визначався індекс подвійного добутку за формулою і спок ПД/max ПД= спок ПД/max ПД, тобто співвідношення подвійного добутку на піку субмаксимального ФН до такого у спокої. Індекс вважався нормальним і спок ПД/ max ПД $\leq 0,5$ (Q=0), при і спок ПД/max ПД>0,5-Q=1. Обстежуваним пацієнтам також проводився 6-хвилинний тест ходьби (6XTX), оцінку пройденої відстані в метрах (6MWD) та інтенсивність задишки за шкалою Borg у балах (задишка Borg (6)) здійснювали за загальновизнаною методикою [26]. Дистанція 6MWD: 426-550 м розцінювалась як еквівалент I функціональному класу, 301-425 м - II, 151-300 - III, 150 м і менше - IV функціональному класу за NYHA [22]. Розрахунковий показник дистанції 6MWD (6MWD_N) проводився за формулами: 6MWD_N=(7,57×зріст в см) - (5,02×вік) (1,76хмаса тіла в кг) - 309 м для чоловіків та 6MWD_N=(2,11× зріст в см) - (2,29хмаса тіла в кг) (5,78×вік) + 667 м - для жінок [27]. Функціональний клас стенокардії оцінювали за стандартною методикою [17]. Індекси визначали як відношення отриманого до розрахункового показника.

Статистичний аналіз отриманих даних здійснювали за допомогою програмних пакетів MedCalc v.15.8.0 (MedCalc Software bvba, 1993-2015, Belgium) та StatSoft STATISTICA 12.5.192.7 (Dell Software Company, 2014, USA). Аналіз відповідності розподілу кількісних ознак до закону нормального розподілу проводили за допомогою W-тесту Шапіро-Уілка. Використано ANOVA для повторних вимірювань (у випадку нормального закону розподілу), критерій Фрідмана (у випадку закону розподілу, відмінного від нормального) та критерій Стьюдента для пов'язаних вибірок (у випадку нормального 
Огляди літератури, оригінальні дослідження, погляд на проблему закону розподілу), критерій Т-Вілкоксона (у випадку закону розподілу, відмінного від нормального). Порівняння абсолютної і відносної (\%) частот виявлення якісних (номінальних і рангових) показників проводили за таблицями спряження (кростабуляції) із оцінюванням точного критерію Фішера для незв'язаних та тесту МакНемара для зв'язаних вибірок. Для визначення незалежних предикторів комбінованої кінцевої точки проводили уніваріантний та покроковий мультиваріантний логістичний ре-

гресійний аналіз. Ступінь зв'язку факторних ознак з ризиком виникнення комбінованої кінцевої точки оцінювали за допомогою відношення шансів (ВШ), для якого визначали 95 \% довірчий інтервал (ДІ). Рівнем статистичної значущості вважали $\mathrm{p}<0,05$.

Результати й обговорення. Обстеженим пацієнтам проводили парні проби із дозованим фізичним навантаженням: ТТ та 6ХТХ під час другого та заключного візитів. Результати досліджень зафіксовані у таблицях 3 і 4.

Таблиця 3. Характеристика кількісних показників ТТ та 6ХTX

\begin{tabular}{|c|c|c|c|}
\hline \multirow{2}{*}{ Показник } & \multicolumn{3}{|c|}{ Середнє значення, $\bar{X} \pm \mathrm{m}(\mathrm{n}=30)$} \\
\hline & II візит & III візит & $\mathrm{p}$ \\
\hline ЧСС спок (уд/хв) & $99,80 \pm 4,00$ & $94,30 \pm 2,60$ & 0,11 \\
\hline САТ спок (мм.Hg) & $134,80 \pm 3,40$ & $134,70 \pm 2,80$ & 0,52 \\
\hline ДАТ спок (мм.Hg) & $95,60 \pm 2,30$ & $93,80 \pm 1,90$ & 0,64 \\
\hline MET & $4,87 \pm 0,38$ & $5,79 \pm 0,38$ & 0,11 \\
\hline MET_N & $9,00 \pm 0,23$ & $9,30 \pm 0,25$ & 0,11 \\
\hline i MET/MET_N (N=1) & $0,54 \pm 0,04$ & $0,63 \pm 0,04$ & 0,14 \\
\hline $\mathrm{TH} \%(1,2,3,4)(\mathrm{N}=1)$ & $3,37 \pm 0,21$ & $3,00 \pm 0,23$ & 0,39 \\
\hline Bт & $119,00 \pm 13,00$ & $144,00 \pm 12,00$ & 0,10 \\
\hline BT_N & $239,40 \pm 6,60$ & $242,10 \pm 5,20$ & 0,11 \\
\hline і Bт/Bт_N (N=1) & $0,49 \pm 0,04$ & $0,58 \pm 0,04$ & 0,16 \\
\hline кДж & $25,90 \pm 5,80$ & $36,50 \pm 7,00$ & 0,08 \\
\hline кДж_N & $41,90 \pm 5,40$ & $52,40 \pm 6,70$ & 0,10 \\
\hline і кДж/кдж_N (N=1) & $0,49 \pm 0,04$ & $0,58 \pm 0,04$ & 0,16 \\
\hline дос max $\mathrm{VO}_{2}$ (мл/кг/хв) & $17,10 \pm 1,30$ & $20,30 \pm 1,30$ & 0,11 \\
\hline оч $\max \mathrm{VO}_{2}$ (мл/кг/хв) & $33,00 \pm 1,10$ & $33,10 \pm 0,90$ & 0,37 \\
\hline $\mathrm{iVO}_{2}(\mathrm{~N}=1)$ & $0,54 \pm 0,04$ & $0,63 \pm 0,04$ & 0,14 \\
\hline оч max ЧСС (уд/хв) & $165,10 \pm 1,40$ & $165,10 \pm 1,60$ & $>0,9$ \\
\hline дос max ЧСС (уд/хв) & $150,90 \pm 3,30$ & $147,40 \pm 3,00$ & 0,50 \\
\hline дос XP (N>62 \%) & $0,56 \pm 0,06$ & $0,59 \pm 0,05$ & 0,44 \\
\hline оч XP (N>62 \%) & $0,73 \pm 0,07$ & $0,79 \pm 0,05$ & 0,21 \\
\hline і дос XP/оч XP (N=1) & $0,79 \pm 0,06$ & $0,76 \pm 0,04$ & 0,73 \\
\hline $\max C A T($ мм Hg) & $160,40 \pm 3,60$ & $169,40 \pm 4,20$ & 0,02 \\
\hline max ДАТ (мм Нg) & $96,10 \pm 2,40$ & $96,00 \pm 2,90$ & 0,87 \\
\hline$\partial o c I P$ & $27,70 \pm 2,10$ & $37,30 \pm 2,80$ & 0,043 \\
\hline max ПД & $241,00 \pm 6,00$ & $250,00 \pm 8,00$ & 0,19 \\
\hline спок ПД & $135,00 \pm 6,00$ & $127,00 \pm 5,00$ & 0,23 \\
\hline і спок ПД/max ПД & $0,56 \pm 0,03$ & $0,52 \pm 0,02$ & 0,03 \\
\hline $\mathrm{Q}$ & $0,48 \pm 0,10$ & $0,36 \pm 0,09$ & 0,22 \\
\hline резерв ПД & $106,4 \pm 7,00$ & $122,50 \pm 6,80$ & 0,047 \\
\hline 七 нав-ня (c) & $171,00 \pm 20,00$ & $211,00 \pm 26,00$ & 0,14 \\
\hline t max ПД (c) & $205,00 \pm 19,00$ & $227,00 \pm 24,00$ & 0,71 \\
\hline $\mathrm{t} \max 4 C C(\mathrm{c})$ & $177,00 \pm 20,00$ & $217,00 \pm 24,00$ & 0,14 \\
\hline t рест (c) & $176,00 \pm 12,00$ & $189,00 \pm 13,00$ & 0,30 \\
\hline задишка Borg (6) (N=0) & $1,68 \pm 0,25$ & $1,90 \pm 0,23$ & 0,50 \\
\hline 6MWD (M) & $391,00 \pm 14,00$ & $374,00 \pm 19,00$ & 0,47 \\
\hline 6MWD_N (M) & $483,20 \pm 11,40$ & $483,00 \pm 11,50$ & 0,64 \\
\hline i 6MWD/6MWD_N (N=1) & $0,82 \pm 0,04$ & $0,78 \pm 0,04$ & 0,19 \\
\hline
\end{tabular}

Примітка: * - відмінність статистично значима, $p<0,05$. 
Огляди літератури, оригінальні дослідження, погляд на проблему

Таблиця 4. Характеристика порядкових показників ТТ та 6ХTX

\begin{tabular}{|l|c|c|c|c|}
\hline \multirow{2}{*}{\multicolumn{2}{|c|}{ Показник }} & \multicolumn{3}{c|}{ Частота, а6с. (\%) } \\
\cline { 3 - 4 } & Taк & II візит & III візит & P \\
\cline { 2 - 4 } XH (так-1, ні-0) & $\mathrm{Hi}$ & $15(55,6)$ & $18(64,3)$ & \multirow{2}{*}{0,23} \\
\hline
\end{tabular}

При порівнянні результатів ТТ та 6XTX у о6стежуваної групи пацієнтів за період 6-місячного спостереження значимо зросли: систолічний артеріальний тиск на фоні субмаксимального ФН (max CAT), інотропний резерв (дос IP) та резерв ПД (резерв ПД), а також зменшився індекс ПД (і спок ПД/max ПД).

Відомо, що артеріальний тиск залежить від серцевого викиду (СВ) і периферійного судинного опору. САТ підвищується зі збільшенням динамічної роботи в результаті збільшення СВ, тоді як діастолічний тиск зазвичай залишається на тому ж рівні або помірно знижується внаслідок вазодилатації судинного русла [19]. Тобто, реакція САТ на ФН відображає зростання СВ. Варто зазначити, що знижена реакція САТ на ФН пов'язана з несприятливим прогнозом. Наприклад, у хворих із $\mathrm{CH}$ реакція САТ на ФН $\epsilon$ незалежним предиктором негативного прогнозу та смертності [28-30]. Важливими $\epsilon$ дані про те, що в амбулаторних хворих на IXC із найбільшим зростанням САТ і чСС у відповідь на ФН найнижчий ризик виникнення інфаркту міокарда, СН, інсульту або ТІА і смерті [31]. Максимальні чСС та САТ на фоні ФН $\epsilon$ значущими предикторами максимального споживання кисню $\mathrm{VO}_{2 \max }$ у пацієнтів із ПФФП [13]. Серед о6стежених пацієнтів якраз мало місце саме збільшення САТ при повторному проведенні ТТ, що може свідчити про зростання СВ і, як наслідок, підвищення толерантності до ФН та покращення прогнозу. Системний артеріальний тиск у хворих на ПФФП при ФН релевантно зростає при більш низькій чСС спокою до навантаження [15]. Саме тому важливо прагнути до кращого контролю ЧСС у даної категорії пацієнтів.

Зростання САТ на фоні ФН протягом періоду спостереження було настільки значущим, що привело до позитивної динаміки у інших показниках, де він використовується для розрахунків. Мається на увазі збільшення інотропного резерву. Інотропний резерв - це різниця САТ при ФН та у спокої, що збільшується за умови підвищення САТ при ФН і відсутності зростання САТ у спокої.

ПД-добуток САТ та ЧСС, відомий маркер споживання кисню міокардом [32]. В основному він використовується у якості індексу толерантності до ФН під час реабілітації або для оцінки ефективності препаратів, які одночасно впливають на САТ і ЧСС [33]. ПД прямо пропорційний роботі, що виконується серцем, і може розглядатися як не- прямий показник споживання міокардом кисню, а також як індекс для оцінки реакції коронарного кровообігу на метаболічні потреби організму як у пацієнтів із IXC, так і в здорових осіб. ПД у спокої в значній мірі пов'язаний зі смертністю у загальній популяції. Зв'язок між ПД і смертністю більш виражений у порівнянні із САТ і ЧСС спокою [34]. У досліджуваної групи пацієнтів протягом періоду спостереження ПД у спокої зменшився, а на фоні ФН навпаки, збільшився. Зафіксовані зміни статистично незначущі, проте значимо зріс резерв ПД, тобто різниця вищезгаданих ПД. Відомо, що під час проведення The Duke Treadmill Score для стратифікації ризику у пацієнтів без $\mathrm{CH}$ резерв ПД виявився найсильнішим предиктором серцевосудинної смертності [35]. Також підвищення резерву ПД пов'язане із підвищенням виживаності. Резерв ПД $є$ прогностично більш потужним фактором, порівняно із виконаним ФН (у МЕТ), максимальною ЧСС, САТ або ЧСС у реституції. Резерв ПД - предиктор прогнозу, незалежний від традиційних клінічних факторів ризику та реакції на ФН [25]. Варто нагадати, що усі пацієнти, що підлягали спостереженню, регулярно приймали ББ, причому у дозах вище середньої (див. табл. 4). ББ знижують ЧСС і САТ як у спокої, так і на фоні ФН. Саме тому у спостережуваних хворих фіксувався знижений хронотропний резерв (ХР). Також вони знижують ПД на фоні ФН [18], тому звичайні нормативні показники оцінки ПД не можуть застосовуватись щодо пацієнтів із терапією ББ [17]. Доза ББ протягом періоду спостереження значимо не змінювалась, тобто не могла вплинути на зростання CAT, IP та резерву ПД. На нашу думку, зростання САТ на фоні субмаксимального ФН та IP пов'язане із збільшенням СВ, настільки значущим, що нівелює знижений XР і хронотропну некомпетентність (ХН) на фоні постійного прийому високих доз ББ і таким чином спричиняє підвищення резерву ПД. Раніше визначено, що досягнення цільового рівня ЧСС $<90$ уд/хв у пацієнтів із ФП у стані спокою може привести до контролю чСС із найменш скомпрометованим СВ [36]. Тобто запропонована нами терапія ББ при адекватному зниженні ЧСС не погіршувала СВ і було досягнуто компромісу між контролем ЧСС та толерантністю хворих із ПФФП до ФН. Ймовірно, таким чином також покращується прогноз таких пацієнтів.

Нами також введений новий показник - iндекс співвідношення ПД у спокої до ПД на фоні 
Огляди літератури, оригінальні дослідження, погляд на проблему

субмаксимальних ФН. Він виявився більш чутливим, ніж резерв ПД, і єдиним показником, що має прямий кореляційний зв'язок із ЧСС.

Наступним етапом дослідження було виявлення критичної ЧСС як предиктора негативної динаміки функціонального стану пацієнтів із ПФФП при 6-місячному спостереженні за даними НП. Здійснений кореляційний аналіз виявив зв'язок індексу співвідношення ПД спокою до ПД на фоні ФН - Q із показником середньодобової чСС (уд/хв) за даними 24-годинного ХМ. При виборі порогу ЧСС, при якому спостерігається підвищення індексу Q, використано метод побудови та аналізу кривих операційних характеристик (ROCкривих). Під час оцінки індексу Q позитивним вважали співідношення $\geq 0,5$, а негативним, відповідно, - <0,5. На рисунку 1 наведена ROC-крива для даного аналізу.

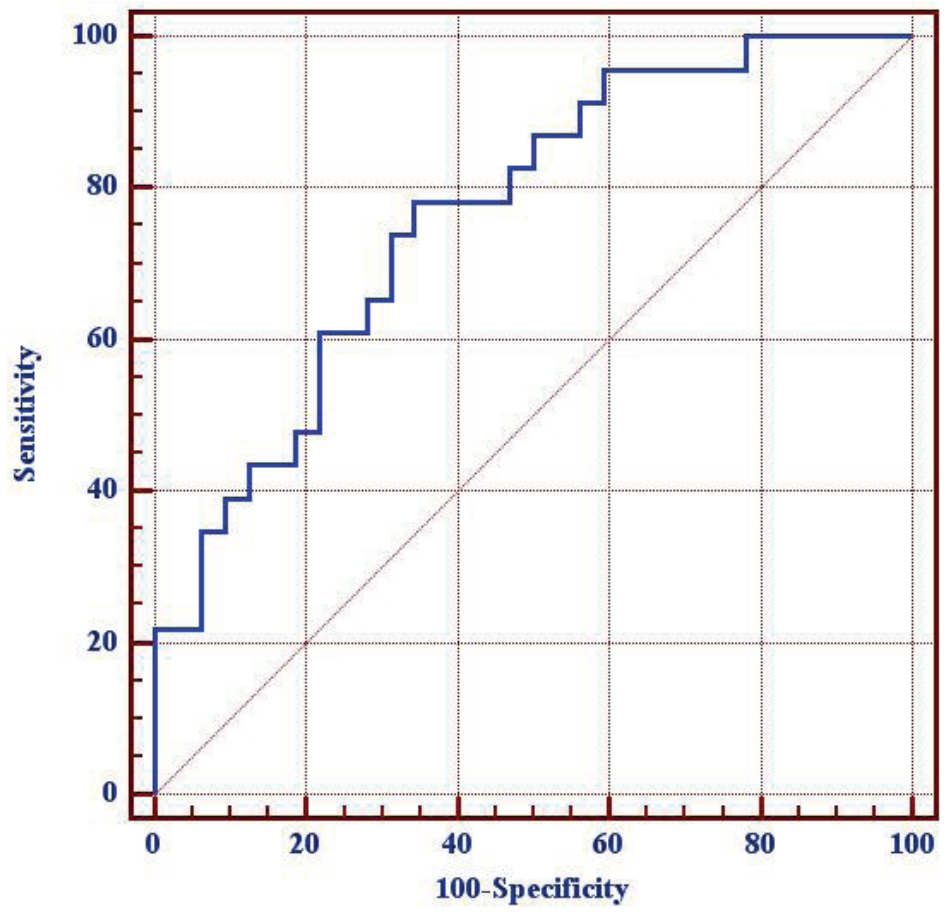

Pис. 1. ROC-крива прогнозування стану за Q за показником сер ЧСC (уд/хв), AUC= 0,77 (95 \% BI 0,63 - 0,87).

При проведенні аналізу встановлено наявність зв'язку індексу Q та ЧСС, площа під кривою $A \cup C=0,77$ (95\% BI 0,63-0,87), статистично значуще більше 0,5 (p<0,001). У таблиці 5 наведено прогностичні характеристики тесту при різних порогових значеннях показника сер ЧСС (уд/хв).

При виборі порогового показника ЧСС виявлено ЧСС crit $=90,5$ уд/хв. Тобто, при середньодобовій чСС>90,5 уд/Хв за даними 24-годинного ХМ ЕКГ прогнозується підвищення індексу Q, a, отже, зростання співідношення ПД у спокої до ПД на фоні субмаксимального ФН і, відповідно, зниження толерантності до ФН, а при ЧСС $\leq 90,5$ уд/хв дані зміни не спостерігаються. Для обраного порогу чутливість тесту становить 78,3 \% (95 \% ВІ $56,3 \%-92,5 \%)$, специфічність - 65,6 \% (95 \% ВІ $46,8 \%-81,4 \%)$.

Вплив зміни показників ПД у спокої та при субмаксимальному ФН на толерантність до ФН у пацієнтів із ПФФП описаний нами вище, тому повторно не зупиняємося на поясненні механізмів взаємозв'язку.
Одним із завдань даного дослідження було порівняння функціонального стану пацієнтів на кожному візиті при обох стратегіях контролю чСС (табл. 6-11). На момент ІІ візиту у 9 пацієнтів вдалось домогтися жорсткого, а у 21 - м'якого контролю ЧСС, а через півроку, при III візиті, відповідно у 15 та 15 хворих.

У досліджуваній групі при жорсткому контролі чСС протягом періоду спостереження значимо зменшилась відстань, пройдена пацієнтами при 6ХTХ. Враховуючи відсутність значимих змін решти показників і допустиму суб'єктивність в оцінці 6XTX вважаємо за можливе знехтувати знайденою відмінністю для оцінки функціонального стану пацієнтів при даній стратегії контролю чСС.

Протягом періоду спостереження статистично значимих змін показників толерантності до ФН при м'якому контролі ЧСС у досліджуваної групи пацієнтів не виявлено.

На наступному етапі проводилось зіставлення отриманих показників ТТ та 6ХTX при обох стратегіях контрою чСС по візитах. 
Огляди літератури, оригінальні дослідження, погляд на проблему

Таблиця 5. Прогностичні характеристики тесту оцінки Q при різних порогових значеннях показника сер ЧСС (уд/хв)

\begin{tabular}{|c|c|c|c|c|}
\hline Показник & Чутливість & $95 \% \mathrm{BI}$ & Специфічність & $95 \% \mathrm{BI}$ \\
\hline$>79,7$ & 100,00 & $85,2-100,0$ & 21,87 & $9,3-40,0$ \\
\hline$>80,6$ & 95,65 & $78,1-99,9$ & 21,87 & $9,3-40,0$ \\
\hline$>84,2$ & 95,65 & $78,1-99,9$ & 40,63 & $23,7-59,4$ \\
\hline$>84,3$ & 91,30 & $72,0-98,9$ & 40,63 & $23,7-59,4$ \\
\hline$>84,4$ & 91,30 & $72,0-98,9$ & 43,75 & $26,4-62,3$ \\
\hline$>86,3$ & 86,96 & $66,4-97,2$ & 43,75 & $26,4-62,3$ \\
\hline$>88,0$ & 86,96 & $66,4-97,2$ & 50,00 & $31,9-68,1$ \\
\hline$>88,1$ & 82,61 & $61,2-95,0$ & 50,00 & $31,9-68,1$ \\
\hline$>88,8$ & 82,61 & $61,2-95,0$ & 53,13 & $34,7-70,9$ \\
\hline$>89,2$ & 78,26 & $56,3-92,5$ & 53,13 & $34,7-70,9$ \\
\hline$>90,5$ & 78,26 & $56,3-92,5$ & 65,62 & $46,8-81,4$ \\
\hline$>90,8$ & 73,91 & $51,6-89,8$ & 65,62 & $46,8-81,4$ \\
\hline$>91,8$ & 73,91 & $51,6-89,8$ & 68,75 & $50,0-83,9$ \\
\hline$>93,7$ & 65,22 & $42,7-83,6$ & 68,75 & $50,0-83,9$ \\
\hline$>93,8$ & 65,22 & $42,7-83,6$ & 71,87 & $53,3-86,3$ \\
\hline$>94,3$ & 60,87 & $38,5-80,3$ & 71,87 & $53,3-86,3$ \\
\hline$>94,9$ & 60,87 & $38,5-80,3$ & 78,12 & $60,0-90,7$ \\
\hline$>95,8$ & 47,83 & $26,8-69,4$ & 78,12 & $60,0-90,7$ \\
\hline$>95,9$ & 47,83 & $26,8-69,4$ & 81,25 & $63,6-92,8$ \\
\hline$>96,2$ & 43,48 & $23,2-65,5$ & 81,25 & $63,6-92,8$ \\
\hline$>96,8$ & 43,48 & $23,2-65,5$ & 87,50 & $71,0-96,5$ \\
\hline$>98,8$ & 39,13 & $19,7-61,5$ & 87,50 & $71,0-96,5$ \\
\hline$>100,7$ & 39,13 & $19,7-61,5$ & 90,62 & $75,0-98,0$ \\
\hline
\end{tabular}

Таблиця 6. Характеристика кількісних показників ТТ та 6ХTX при жорсткому контролі чСС

\begin{tabular}{|c|c|c|c|}
\hline \multirow{2}{*}{ Показник } & \multicolumn{3}{|c|}{ Середнє значення, $\bar{X} \pm \mathrm{m}$} \\
\hline & II візит & III візит & $p$ \\
\hline 1 & 2 & 3 & 4 \\
\hline ЧСС спок (уд/хв) & $81,56 \pm 3,18$ & $88,57 \pm 3,13$ & 0,28 \\
\hline САТ спок $(\mathrm{Mм}, \mathrm{Hg})$ & $135,11 \pm 5,87$ & $134,36 \pm 3,48$ & 0,79 \\
\hline ДАТ спок (мм, Нg) & $90,44 \pm 3,61$ & $91,43 \pm 2,24$ & 0,47 \\
\hline MET & $5,82 \pm 0,86$ & $5,95 \pm 0,61$ & 0,40 \\
\hline MET_N & $9,58 \pm 0,54$ & $9,56 \pm 0,43$ & 0,48 \\
\hline i MET/MET_N (N=1) & $0,61 \pm 0,09$ & $0,62 \pm 0,06$ & 0,54 \\
\hline $\mathrm{TH} \%(1,2,3,4)(\mathrm{N}=1)$ & $2,89 \pm 0,51$ & $3,00 \pm 0,31$ & 0,58 \\
\hline BT & $153,88 \pm 29,85$ & $145,37 \pm 17,88$ & 0,45 \\
\hline BT_N & $263,36 \pm 9,23$ & $246,11 \pm 6,17$ & 0,14 \\
\hline i Bт/BT_N (N=1) & $0,58 \pm 0,10$ & $0,58 \pm 0,06$ & 0,53 \\
\hline кДж & $44,34 \pm 14,34$ & $39,62 \pm 10,77$ & 0,21 \\
\hline кДж_N & $61,41 \pm 11,72$ & $57,50 \pm 10,60$ & 0,21 \\
\hline і кДж/кдж_N (N=1) & $0,58 \pm 0,10$ & $0,58 \pm 0,06$ & 0,53 \\
\hline дос max VO & $20,38 \pm 3,02$ & $20,83 \pm 2,13$ & 0,40 \\
\hline оч max VO & $33,55 \pm 1,87$ & $33,84 \pm 1,44$ & 0,31 \\
\hline $\mathrm{iVO}_{2}(\mathrm{~N}=1)$ & $0,61 \pm 0,09$ & $0,62 \pm 0,06$ & 0,54 \\
\hline оч max ЧСС (уд/хв) & $166,30 \pm 2,01$ & $164,76 \pm 1,87$ & 0,13 \\
\hline дос max ЧСС (уд/хв) & $141,67 \pm 5,74$ & $141,07 \pm 4,37$ & 0,63 \\
\hline дос XP (N>62 \%) & $0,76 \pm 0,10$ & $0,62 \pm 0,08$ & 0,36 \\
\hline
\end{tabular}




\begin{tabular}{|c|c|c|c|}
\hline 1 & 2 & 3 & 4 \\
\hline 04 XP (N>62 \%) & $1,06 \pm 0,09$ & $0,90 \pm 0,08$ & 0,19 \\
\hline і дос XP/оч XP (N=1) & $0,70 \pm 0,09$ & $0,69 \pm 0,06$ & 0,88 \\
\hline $\max$ CAT (MM.Hg) & $164,00 \pm 7,41$ & $166,86 \pm 5,24$ & 0,58 \\
\hline max ДАТ (мМ.Hg) & $90,67 \pm 3,04$ & $91,29 \pm 3,14$ & 0,11 \\
\hline дос IP & $28,89 \pm 4,81$ & $32,50 \pm 5,56$ & 0,73 \\
\hline $\max$ ПД & $230,98 \pm 11,27$ & $235,90 \pm 11,36$ & 0,80 \\
\hline спок ПД & $110,45 \pm 6,74$ & $119,40 \pm 5,75$ & 0,46 \\
\hline і спок ПД/max ПД & $0,48 \pm 0,03$ & $0,52 \pm 0,03$ & 0,48 \\
\hline Q & $0,22 \pm 0,15$ & $0,43 \pm 0,14$ & 0,22 \\
\hline резерв ПД & $120,54 \pm 10,70$ & $116,50 \pm 11,49$ & 0,62 \\
\hline t нав-ня (c) & $233,89 \pm 45,03$ & $229,07 \pm 45,03$ & 0,26 \\
\hline $\mathrm{t} \max$ ПД (c) & $270,11 \pm 42,02$ & $254,64 \pm 37,50$ & 0,28 \\
\hline $\mathrm{t} \max 4 \mathrm{CC}(\mathrm{c})$ & $243,89 \pm 44,52$ & $245,57 \pm 38,67$ & 0,38 \\
\hline t рест (c) & $195,33 \pm 27,29$ & $167,43 \pm 18,34$ & 0,75 \\
\hline задишка Borg (6) (N=0) & $1,50 \pm 0,46$ & $1,47 \pm 0,30$ & 0,14 \\
\hline 6MWD (M) & $403,89 \pm 23,42$ & $393,33 \pm 28,40$ & 0,02 \\
\hline 6MWD_N (M) & $499,61 \pm 30,71$ & $488,98 \pm 19,28$ & 0,64 \\
\hline i 6MWD/6MWD_N (N=1) & $0,84 \pm 0,09$ & $0,82 \pm 0,06$ & 0,05 \\
\hline
\end{tabular}

Примітка: * - відмінність статистично значима, $\mathrm{p}<0,05$.

Таблиця 7. Характеристика порядкових показників ТТ та 6ХTX при жорсткому контролі чСС

\begin{tabular}{|c|c|c|c|c|}
\hline \multirow{2}{*}{\multicolumn{2}{|c|}{ Показник }} & \multicolumn{3}{|c|}{ Частота, а6с. (\%) } \\
\cline { 3 - 4 } XН (так-1, ні-0) & Tак & II & III & P \\
\cline { 2 - 4 } & $\mathrm{Hi}$ & $7(22,20)$ & $8(57,14)$ & 0,25 \\
\hline
\end{tabular}

Таблиця 8. Характеристика кількісних показників ТТ та 6XTX при м'якому контролі чСС

\begin{tabular}{|c|c|c|c|}
\hline \multirow{2}{*}{ Показник } & \multicolumn{3}{|c|}{ Середнє значення, $\bar{X} \pm \mathrm{m}$} \\
\hline & II візит & III візит & $\mathrm{p}$ \\
\hline 1 & 2 & 3 & 4 \\
\hline ЧСС спок (уд/хв) & $108,89 \pm 4,32$ & $100,07 \pm 3,47$ & 0,33 \\
\hline САТ спок (мм Hg) & $134,61 \pm 4,23$ & $135,00 \pm 4,56$ & 0,56 \\
\hline ДАТ спок (мм Нg) & $98,17 \pm 2,80$ & $96,14 \pm 3,11$ & 0,80 \\
\hline MET & $4,39 \pm 0,34$ & $5,63 \pm 0,48$ & 0,18 \\
\hline MET_N & $8,69 \pm 0,19$ & $9,02 \pm 0,24$ & 0,30 \\
\hline i MET/MET_N (N=1) & $0,50 \pm 0,03$ & $0,63 \pm 0,05$ & 0,30 \\
\hline $\mathrm{TH} \%(1,2,3,4)(\mathrm{N}=1)$ & $3,61 \pm 0,16$ & $3,00 \pm 0,38$ & 0,69 \\
\hline BT & $102,10 \pm 10,91$ & $142,76 \pm 17,00$ & 0,26 \\
\hline BT_N & $227,41 \pm 7,44$ & $237,99 \pm 8,37$ & 0,77 \\
\hline i BT/BT_N (N=1) & $0,44 \pm 0,04$ & $0,59 \pm 0,06$ & 0,30 \\
\hline кДж & $16,68 \pm 3,75$ & $33,29 \pm 9,23$ & 0,37 \\
\hline кДж_N & $32,20 \pm 4,19$ & $47,22 \pm 8,52$ & 0,69 \\
\hline і кДж/кдж_N (N=1) & $0,44 \pm 0,04$ & $0,59 \pm 0,06$ & 0,30 \\
\hline дос max VO & $15,38 \pm 1,20$ & $19,73 \pm 1,69$ & 0,18 \\
\hline оч max $\mathrm{VO}_{2}$ (мл/кг/хв) & $32,78 \pm 1,43$ & $32,29 \pm 1,07$ & 0,95 \\
\hline $\mathrm{i} \mathrm{VO}_{2}(\mathrm{~N}=1)$ & $0,50 \pm 0,03$ & $0,63 \pm 0,05$ & 0,30 \\
\hline оч max ЧСС (уд/хв) & $164,53 \pm 1,93$ & $165,48 \pm 2,54$ & 0,35 \\
\hline дос max ЧСС (уд/хв) & $155,44 \pm 3,67$ & $153,71 \pm 3,36$ & 0,99 \\
\hline дос XР (N>62 \%) & $0,46 \pm 0,06$ & $0,55 \pm 0,05$ & 0,45 \\
\hline 04 XP (N>62 \%) & $0,55 \pm 0,06$ & $0,67 \pm 0,05$ & 0,55 \\
\hline і дос XP/оч XP (N=1) & $0,85 \pm 0,07$ & $0,84 \pm 0,06$ & 0,73 \\
\hline
\end{tabular}




\begin{tabular}{|l|c|c|c|}
\hline \multicolumn{1}{|c|}{1} & 2 & 3 & 4 \\
\hline max САТ (мм Hg) & $158,67 \pm 4,08$ & $171,86 \pm 6,67$ & 0,09 \\
\hline max ДАТ (мм Hg) & $98,83 \pm 3,10$ & $100,79 \pm 4,56$ & 0,63 \\
\hline дос IP & $24,06 \pm 2,69$ & $36,86 \pm 3,09$ & 0,03 \\
\hline max ПД & $245,83 \pm 7,16$ & $263,36 \pm 10,36$ & 0,14 \\
\hline спок ПД & $146,57 \pm 7,16$ & $134,91 \pm 6,59$ & 0,39 \\
\hline i спок ПД/max ПД & $0,60 \pm 0,03$ & $0,51 \pm 0,02$ & 0,15 \\
\hline Q & $0,61 \pm 0,12$ & $0,29 \pm 0,13$ & 0,31 \\
\hline резерв ПД & $99,26 \pm 8,82$ & $128,44 \pm 7,21$ & 0,09 \\
\hline t нав-ня (c) & $139,72 \pm 15,55$ & $192,86 \pm 31,95$ & 0,86 \\
\hline t max ПД (c) & $173,06 \pm 14,90$ & $199,07 \pm 28,52$ & 0,62 \\
\hline t max ЧCC (c) & $142,94 \pm 15,35$ & $188,21 \pm 28,33$ & 0,91 \\
\hline t рест (c) & $166,33 \pm 11,48$ & $210,00 \pm 17,75$ & 0,02 \\
\hline 3адишка Bогg (6) (N=0) & $1,76 \pm 0,30$ & $2,33 \pm 0,33$ & 0,11 \\
\hline 6MWD (м) & $385,95 \pm 17,98$ & $354,95 \pm 25,77$ & 0,06 \\
\hline 6MWD_N (м) & $476,18 \pm 9,91$ & $476,95 \pm 13,04$ & 0,80 \\
\hline i 6MWD/6MWD_N (N=1) & $0,81 \pm 0,04$ & $0,75 \pm 0,06$ & 0,08 \\
\hline
\end{tabular}

Таблиця 9. Характеристика порядкових показників ТТ та 6XТХ при м'якому контролі чсС

\begin{tabular}{|c|l|c|c|c|}
\hline \multicolumn{2}{|c|}{ Показник } & \multicolumn{3}{c|}{ Частота, а6с. (\%) } \\
\cline { 3 - 4 } & Tак & II візит & III візит & P \\
\cline { 2 - 4 } XН (так-1, ні-0) & $\mathrm{Hi}$ & $5(27,20)$ & $10(71,40)$ & 0,07 \\
\hline
\end{tabular}

Таблиця 10. Характеристика кількісних показників ТТ та 6ХТХ при жорсткому та м'якому контролі чСС

\begin{tabular}{|c|c|c|c|c|c|c|}
\hline \multirow{2}{*}{ Показник } & \multicolumn{6}{|c|}{ Середнє значення, $\bar{X} \pm \mathrm{m}$} \\
\hline & $\begin{array}{l}\text { II візит, } \\
\text { жінки }\end{array}$ & $\begin{array}{l}\text { II візит, } \\
\text { чоловіки }\end{array}$ & $p$ & $\begin{array}{l}\text { III візит, } \\
\text { жінки }\end{array}$ & $\begin{array}{l}\text { III візит, } \\
\text { чоловіки }\end{array}$ & $p$ \\
\hline 1 & 2 & 3 & 4 & 5 & 6 & 7 \\
\hline ЧСС спок (уд/хв) & $81,56 \pm 3,18$ & $108,89 \pm 4,32$ & $<0,001$ & $88,57 \pm 3,13$ & $100,07 \pm 3,47$ & 0,02 \\
\hline САТ спок (мм Нg) & $135,11 \pm 5,87$ & $134,61 \pm 4,23$ & 0,95 & $134,36 \pm 3,48$ & $135,00 \pm 4,56$ & 0,91 \\
\hline ДАТ спок (мм Нg) & $90,44 \pm 3,61$ & $98,17 \pm 2,80$ & 0,12 & $91,43 \pm 2,24$ & $96,14 \pm 3,11$ & 0,23 \\
\hline MET & $5,82 \pm 0,86$ & $4,39 \pm 0,34$ & 0,50 & $5,95 \pm 0,61$ & $5,63 \pm 0,48$ & 0,83 \\
\hline MET_N & $9,58 \pm 0,54$ & $8,69 \pm 0,19$ & 0,31 & $9,56 \pm 0,43$ & $9,02 \pm 0,24$ & 0,38 \\
\hline i MET / MET_N & $0,61 \pm 0,09$ & $0,50 \pm 0,03$ & 0,18 & $0,62 \pm 0,06$ & $0,63 \pm 0,05$ & 0,93 \\
\hline TH \% & $2,89 \pm 0,51$ & $3,61 \pm 0,16$ & 0,50 & $3,00 \pm 0,31$ & $3,00 \pm 0,38$ & 0,78 \\
\hline Вт & $153,88 \pm 29,85$ & $102,10 \pm 10,91$ & 0,50 & $145,37 \pm 17,88$ & $142,76 \pm 17,00$ & 0,92 \\
\hline$B m_{-} N$ & $263,36 \pm 9,23$ & $227,41 \pm 7,44$ & 0,01 & $246,11 \pm 6,17$ & $237,99 \pm 8,37$ & 0,44 \\
\hline i Bт / BT_N & $0,58 \pm 0,10$ & $0,44 \pm 0,04$ & 0,16 & $0,58 \pm 0,06$ & $0,59 \pm 0,06$ & 0,95 \\
\hline кДж & $44,34 \pm 14,34$ & $16,68 \pm 3,75$ & 0,31 & $39,62 \pm 10,77$ & $33,29 \pm 9,23$ & 0,81 \\
\hline кДж_N & $61,41 \pm 11,72$ & $32,20 \pm 4,19$ & 0,40 & $57,50 \pm 10,60$ & $47,22 \pm 8,52$ & 0,65 \\
\hline і кДж / кДж_N & $0,58 \pm 0,10$ & $0,44 \pm 0,04$ & 0,16 & $0,58 \pm 0,06$ & $0,59 \pm 0,06$ & 0,95 \\
\hline дос max $\mathrm{VO}_{2}$ (мл/кг/хв) & $20,38 \pm 3,02$ & $15,38 \pm 1,20$ & 0,50 & $20,83 \pm 2,13$ & $19,73 \pm 1,69$ & 0,83 \\
\hline Оч $\max \mathrm{VO}_{2}$ (мл/Кг/хв) & $33,55 \pm 1,87$ & $32,78 \pm 1,43$ & 0,95 & $33,84 \pm 1,44$ & $32,29 \pm 1,07$ & 0,46 \\
\hline $\mathrm{i} \mathrm{VO}_{2}$ & $0,61 \pm 0,09$ & $0,50 \pm 0,03$ & 0,18 & $0,62 \pm 0,06$ & $0,63 \pm 0,05$ & 0,93 \\
\hline оч $\max$ ЧСС (уд/хв) & $166,30 \pm 2,01$ & $164,53 \pm 1,93$ & 0,57 & $164,76 \pm 1,87$ & $165,48 \pm 2,54$ & 0,82 \\
\hline 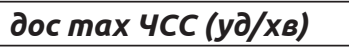 & $141,67 \pm 5,74$ & $155,44 \pm 3,67$ & 0,046 & $141,07 \pm 4,37$ & $153,71 \pm 3,36$ & 0,03 \\
\hline$\partial o c X P$ & $0,76 \pm 0,10$ & $0,46 \pm 0,06$ & 0,008 & $0,62 \pm 0,08$ & $0,55 \pm 0,05$ & 0,48 \\
\hline $04 X P$ & $1,06 \pm 0,09$ & $0,55 \pm 0,06$ & $<0,001$ & $0,90 \pm 0,08$ & $0,67 \pm 0,05$ & 0,03 \\
\hline і дос XР/ оч XР & $0,70 \pm 0,09$ & $0,85 \pm 0,07$ & 0,19 & $0,69 \pm 0,06$ & $0,84 \pm 0,06$ & 0,09 \\
\hline $\max$ CAT (MM Hg) & $164,00 \pm 7,41$ & $158,67 \pm 4,08$ & 0,50 & $166,86 \pm 5,24$ & $171,86 \pm 6,67$ & 0,56 \\
\hline
\end{tabular}




\begin{tabular}{|c|c|c|c|c|c|c|}
\hline 1 & 2 & 3 & 4 & 5 & 6 & 7 \\
\hline max ДАТ (мм Hg) & $90,67 \pm 3,04$ & $98,83 \pm 3,10$ & 0,11 & $91,29 \pm 3,14$ & $100,79 \pm 4,56$ & 0,10 \\
\hline дос IP & $28,89 \pm 4,81$ & $24,06 \pm 2,69$ & 0,35 & $32,50 \pm 5,56$ & $36,86 \pm 3,09$ & 0,50 \\
\hline max ПД & $230,98 \pm 11,27$ & $245,83 \pm 7,16$ & 0,26 & $235,90 \pm 11,36$ & $263,36 \pm 10,36$ & 0,09 \\
\hline спок ПД & $110,45 \pm 6,74$ & $146,57 \pm 7,16$ & 0,004 & $119,40 \pm 5,75$ & $134,91 \pm 6,59$ & 0,28 \\
\hline і спок ПД/ $\max$ ПД & $0,48 \pm 0,03$ & $0,60 \pm 0,03$ & 0,02 & $0,52 \pm 0,03$ & $0,51 \pm 0,02$ & 0,92 \\
\hline $\mathrm{Q}$ & $0,22 \pm 0,15$ & $0,61 \pm 0,12$ & 0,36 & $0,43 \pm 0,14$ & $0,29 \pm 0,13$ & 0,46 \\
\hline резерв ПД & $120,54 \pm 10,70$ & $99,26 \pm 8,82$ & 0,31 & $116,50 \pm 11,49$ & $128,44 \pm 7,21$ & 0,39 \\
\hline 七 нав-ня (c) & $233,89 \pm 45,03$ & $139,72 \pm 15,55$ & 0,61 & $229,07 \pm 45,03$ & $192,86 \pm 31,95$ & 0,65 \\
\hline $\mathrm{t} \max$ ПД (c) & $270,11 \pm 42,02$ & $173,06 \pm 14,90$ & 0,01 & $254,64 \pm 37,50$ & $199,07 \pm 28,52$ & 0,25 \\
\hline $\mathrm{t} \max$ ЧCC (c) & $243,89 \pm 44,52$ & $142,94 \pm 15,35$ & 0,01 & $245,57 \pm 38,67$ & $188,21 \pm 28,33$ & 0,28 \\
\hline t рест (c) & $195,33 \pm 27,29$ & $166,33 \pm 11,48$ & 0,26 & $167,43 \pm 18,34$ & $210,00 \pm 17,75$ & 0,11 \\
\hline задишка Borg (6) & $1,50 \pm 0,46$ & $1,76 \pm 0,30$ & 1,00 & $1,47 \pm 0,30$ & $2,33 \pm 0,33$ & 0,17 \\
\hline 6MWD (M) & $403,89 \pm 23,42$ & $385,95 \pm 17,98$ & 0,57 & $393,33 \pm 28,40$ & $354,95 \pm 25,77$ & 0,32 \\
\hline 6MWD_N (M) & $499,61 \pm 30,71$ & $476,18 \pm 9,91$ & 0,35 & $488,98 \pm 19,28$ & $476,95 \pm 13,04$ & 0,61 \\
\hline i 6MWD / 6MWD_N & $0,84 \pm 0,09$ & $0,81 \pm 0,04$ & 0,75 & $0,82 \pm 0,06$ & $0,75 \pm 0,06$ & 0,44 \\
\hline
\end{tabular}

Примітка: * - відмінність статистично значима, $p<0,05$.

Таблиця 11. Характеристика порядкових показників ТТ та 6XTX при жорсткому та м'якому контролі чСС

\begin{tabular}{|c|c|c|c|c|c|c|c|}
\hline \multirow{2}{*}{\multicolumn{2}{|c|}{ Показник }} & \multicolumn{6}{|c|}{ Частота, абс. ( \%) } \\
\hline & & $\begin{array}{l}\text { II візит, } \\
\text { жінки }\end{array}$ & $\begin{array}{l}\text { II візит, } \\
\text { чоловіки }\end{array}$ & $\mathrm{P}$ & $\begin{array}{c}\text { III візит, } \\
\text { жінки }\end{array}$ & $\begin{array}{l}\text { III візит, } \\
\text { чоловіки }\end{array}$ & $P$ \\
\hline \multirow{2}{*}{$\begin{array}{c}\mathrm{XH} \\
(\text { так-1, нi-0) }\end{array}$} & Так & $2(22,22)$ & $13(65,00)$ & \multirow{2}{*}{0,52} & $8(57,14)$ & $10(71,43)$ & \multirow{2}{*}{0,66} \\
\hline & $\mathrm{Hi}$ & $7(77,7)$ & $5(25,00)$ & & $6(42,86)$ & $4(28,57)$ & \\
\hline
\end{tabular}

У обстежуваної групи пацієнтів при зіставленні даних ТТ та 6XTX за умови досягнення жорсткого контролю ЧСС протягом періоду спостереження значимо нижчі ЧСС спокою (ЧСС спок), ЧСС на фоні субмаксимального ФН (дос max ЧСС) (2 і 3 візити) та подвійний добуток у спокої (спок ПД), індекс подвійного добутку (i спок ПД/max ПД) (2 візит), а також вищий хронотропний резерв міокарда (дос XР) (2 візит). Виявлені зміни розрахункових величин очікуваних ФН у Ватах (Bт_N) та хронотропного резерву (оч XP) нами до уваги не брались, так як вони не впливали на індекси досліджуваних показників. Отримані дані можна інтерпретувати наступним чином: нижча ЧСС у спокої та при ФН - очікуваний результат, який власне і визначав стратегію контролю. Відомо, що відповідь ЧСС на навантаження при ФП характеризується початковим зменшенням ЧСС, сповільненим їі зростанням на ранніх стадіях НП і посиленою відповіддю при подовженні навантаження [17]. На нашу думку, прийом ББ нівелював фізіологічне підвищення ЧСС на піку субмаксимального ФН, причому більш виражено при жорсткому контролі ЧСС. Зниження ЧСС було настільки значущим, що привело до позитивної динаміки у інших показниках, де він використовується для розрахунків. Мається на увазі підвищення резерву (XР). ХР - похідна величина від згаданих показ- ників ЧСС, тому його зростання свідчить про адекватний контроль ЧСС.

Згідно з даними літератури, низький ХР є незалежним предиктором серцево-судинних подій [37]. XН, а, отже, і низький XР, пов'язана із вищою серцево-судинною смертністю, нижчою толерантністю до ФН та $\epsilon$ більш сильним прогностичним маркером, ніж клінічні дані та традиційні маркери ризику. ББ мають мінімальний вплив на прогностичну силу ХH [38]. ХН пов'язана із підвищеним ризиком смерті у здорових жінок [20]. Також відомо, що XН значно частіше зустрічається у пацієнтів із $\mathrm{CH}$ та ЗФВ ЛШ, порівняно із здоровими людьми [39]. У пацієнтів із ЗФВ ЛШ та низькою толерантністю до ФН або нездатністю пройти НП на $34 \%$ менший розмір порожнини лш, у порівнянні із пацієнтами із збереженою толерантністю до $Ф$ Н. Це зменшення розміру камери Лш пов'язане із концентричною гіпертрофією та зворотним збільшенням ЧСС спокою. Крім того, резерв СВ додатково знижується через ХН та індуковане тахікардією зменшення об'єму ЛШ [40]. Наявність ХН $€$ основним предиктором низької толерантності до ФН у хворих на СН та синусовим ритмом [41]. XН, а саме низький XР, $\epsilon$ сильним предиктором тяжкості функціонального класу $\mathrm{CH}$ за шкалою NYHA i max $\mathrm{VO}_{2}$ незалежно від терапії ББ та їх дози [42]. Важливим $\epsilon$ той факт, що у хво- 
Огляди літератури, оригінальні дослідження, погляд на проблему

рих на СН, які отримують ББ у оптимальних дозах, зниження $\mathrm{XP}<0,6$ пов'язане з несприятливими клінічними наслідками [43]. Щодо пацієнтів із ПФФП, то у тих із них, які підлягають жорсткому контролю ЧСС, зниження $\mathrm{XP} \leq 0,4 \in$ важливим предиктором 4-річної виживаності без госпіталізації із приводу СН [16]. У обстежуваних нами пацієнтів XР був вищим саме при застосуванні стратегії жорсткого контролю ЧСС, тому можна стверджувати, що вона більш прийнятна для покращення прогнозу у даної категорії пацієнтів. Враховуючи те, що попередження прогресування $\mathrm{CH} \in$ одним із основних завдань при лікуванні ПФФП, жорсткий контроль показує свою перевагу перед м'яким і у цьому аспекті. На обґрунтуванні значення і впливу ПД спокою та індексу ПД для контролю чСС не зупиняємось, так як вони викладені вище.

Отже, за умови досягнення жорсткого контролю ЧСС, через 2 місяці спостережень має місце покращення толерантності пацієнтів до фізичних навантажень, яке нівелюється через півроку. Про- те вплив як на ЧСС спокою, так і на ЧСС при ФН зберігається протягом всього періоду спостережень.

Висновки. 1. Протягом 6-місячного спостереження у хворих на ПФФП неклапанної етіології при застосуванні ББ відзначається покращення толерантності до фізичних навантажень, що свідчить про адекватний контроль чСС.

2. Предиктором зниження толерантності до фізичних навантажень у пацієнтів із ПФФП неклапанної етіології при піврічному спостереженні $\epsilon$ середньодобова ЧСС>90,5 уд/Хв за даними 24-годинного ХМ ЕКГ.

3. Жорсткий контроль чСС має перевагу перед м'яким щодо покращення функціонального стану пацієнтів та їх прогнозу.

Перспективи подальших досліджень. Важливою є можливість більш тривалого спостереження для вивчення виживаності пацієнтів. Також цікавим видається зіставлення отриманих результатів із даними ЕхоКГ та проведення оцінки якості життя даної когорти хворих.

\section{ЛІТЕРАТУРА}

1. Epidemiology of atrial fibrillation: European perspective / M. Zoni-Berisso, F. Lercari, T. Carazza, S. Domenicucci // Clin. Epidemiol. - 2014. - Vol. 6. - P. 213-220.

2. Clinical characteristics, management, and control of permanent vs. nonpermanent atrial fibrillation: insights from the RealiseAF survey / J. Murin, L. Naditch-Brûlé, S. Brette [et al.] // PLoS One. - 2014. - Vol. 9 (1). - E86443.

3. Chiang C. E. Distribution and risk profile of paroxysmal, persistent, and permanent atrial fibrillation in routine clinical practice: insight from the real-life global survey evaluating patients with atrial fibrillation international registry / C. E. Chiang, L. Naditch-Brûlé, J. Murin // Circ. Arrhythm. Electrophysiol. - 2012. - Vol. 5 (4). - P. 632-639.

4. Steinberg B. A. Increased heart rate is associated with higher mortality in patients with atrial fibrillation (AF): Results from the outcomes registry for better informed treatment of AF (ORBIT-AF) / B. A. Steinberg, S. Kim, L. Thomas // J. Am. Heart. Assoc. - 2015. - Vol. 4 (9). - E002031.

5. 2016 ESC Guidelines for the management of atrial fibrillation developed in collaboration with EACTS / P. Kirchhof, S. Benussi, D. Kotecha [et al.] // Eur. Heart. J. - 2016. Vol. 37 (38). - P. 2893-2962.

6. 2016 ESC Guidelines for the diagnosis and treatment of acute and chronic heart failure / P. Ponikowski, A. A. Voors, S. D. Anker [et al.] // Eur. Heart. J. - 2016. Vol. 37 (27). - P. 2129-2200.

7. Lenient vs. strict rate control in patients with atrial fibrillation and heart failure: a post-hoc analysis of the RACE II study / B. A. Mulder, Van D. J. Veldhuisen, H. J. Crijns [et al.] // Eur. J. Heart Fail. - 2013 - Vol. 15 (11). P. 311-318.

8. Lenient versus strict rate control in patients with atrial fibrillation / Van I. C. Gelder, H. F. Groenveld, J. G. M. Harry [et al.] // N. Engl. J. Med. - 2010. - Vol. 362 (15). P. 1363-1373.
9. Influence of heart rate on quality of life in patients with chronic atrial fibrillation / J. Jaber, C. Cirenza, J. Jaber [et al.] // Clin. Cardiol. - 2010. - Vol. 33 (4). - P. 28-32.

10. Kato $Y$. The relationship between resting heart rate and peak VO2: a comparison of atrial fibrillation and sinus rhythm / Y. Kato, S. Suzuki, T. Uejima // Eur. J. Prev. Cardiol. - 2016. - Vol. 23 (13). - P. 1429-1436.

11. Does intensity of rate-control influence outcome in atrial fibrillation? An analysis of pooled data from the RACE and AFFIRM studies / I. C. Van Gelder, D. G. Wyse, M. L. Chandler [et al.] // Europace. - 2006. - Vol. 8 (11). - P. 935-942.

12. Impact of atrial fibrillation on exercise capacity in heart failure with preserved ejection fraction: a RELAX trial ancillary study / R. Zakeri, B. A. Borlaug, S. E. McNulty [et al.] // Circ. Heart. Fail. - 2014. - Vol. 7 (1). - P. 123-130.

13. Maximal exercise testing and gas exchange in patients with chronic atrial fibrillation / J. E. Atwood, J. Myers, M. Sullivan [et al.] // J. Am. Coll. Cardiol. -1988. - Vol. 11 (3).P. 508-513.

14. Effect of beta-adrenergic blockade on exercise performance in patients with chronic atrial fibrillation / J. E. Atwood, M. Sullivan, S. Forbes [et al.] // J. Am. Coll. Cardiol. - 1987. - Vol. 10 (2). - P. 314-320.

15. A computational study on the relation between resting heart rate and atrial fibrillation hemodynamics under exercise / Anselmino M., Scarsoglio S., Saglietto A., [et al.] // PLoS One. - 2017. - Vol. 12 (1). - E0169967.

16. Predictive value of the heart rate reserve in patients with permanent atrial fibrillation treated according to a strict rate-control strategy / N. De Schryver, C. Scavée, S. Marchandise [et al.] // Europace. - 2014. - Vol. 16 (8). P. 1125-1130.

17. Жарінов О.Й. Навантажувальні проби в кардіології Навчальний посібник / О. Й. Жарінов, В. О. Куць, Н. В. Тхор. - К. : Мед. світу, 2006. - 89 с. 


\section{Огляди літератури, оригінальні дослідження, погляд на проблему}

18. Canadian cardiovascular society atrial fibrillation guidelines 2010: rate and rhythm management / A. M. Gillis, A. Verma, M. Talajic [et al.] // Can. J. Cardiol. - 2011. Vol. 27 (1). - P. 47-59.

19. Exercise standards for testing and training: a scientific statement from the American Heart Association / G. F. Fletcher, P. A. Ades, P. Kligfield [et al.] // Circulation. 2013. - Vol. 128 (8). - P. 873-934.

20. Heart rate response to exercise stress testing in asymptomatic women:the st. James women take heart project / M. Gulati, L. J. Shaw, R. A. Thisted [et al.] // Circulation. - 2010. - Vol. 122 (2). - P. 130-137.

21. Rexhepi M. Prediction of VO2max based on age, body mass, and resting heart rate / M. Rexhepi, B. Brestovci // Human Movement. - 2014. - Vol. 15 (1). - P. 56-59.

22. Fletcher G. F. Exercise standards for testing and training: a statement for healthcare professionals from the American Heart Association / G. F. Fletcher, G. J. Balady, E. A. Amsterdam // Circulation. - 2001. - Vol. 104 (14). P. 1694-1740.

23. Аронов Д. М. Функциональные пробы в кардиологии / Д. М. Аронов, В. П. Лупанов. - М. : Медпресс-информ, 2002. - 296 C.

24. Khan M. N. Chronotropic incompetence as a predictor of death among patients with normal electrograms taking beta blockers (metoprolol or atenolol) / M. N. Khan, C. E. Pothier, M. S. Lauer // Am. J. Cardiol. 2005. - Vol. 96 (9). - P. 1328-1333.

25. Prognostic value of double product reserve / A. H. Sadrzadeh Rafie, G. W. Sungar, F. E. Dewey [et al.] // Eur. J. Cardiovasc. Prev. Rehabil. - 2008. - Vol. 15 (5). P. 541-547.

26. American Thoracic Society. ATS statement: guidelines for the six-minute walk test // Am. J. Respir. Crit. Care Med. - 2002. - Vol. 166 (1). - P. 111-117.

27. Enright P. L. Reference equations for the sixminute walk in healthy adults / P. L. Enright, D. L. Sherrill // Am. J. Respir. Crit. Care Med. -1998. - Vol. 158 (5). P. 1384-1387.

28. Nishiyama Y. Systolic blood pressure response to exercise as a predictor of mortality in patients with chronic heart failure / Y. Nishiyama, H. Morita, H. Harada // Int. Heart J. - 2010. - Vol. 51 (2). - P. 111-115.

29. Cardiopulmonary exercise testing identifies low risk patients with heart failure and severely impaired exercise capacity for heart transplantation / N. Osada, B. R. Chaitman, L. W. Miller [et al.] // J. Am. Coll. Cardiol. 1998. - Vol. 31 (3). - P. 577-582.

30. Fagard R. Prognostic significance of exercise versus resting blood pressure in patients with chronic heart failure / R. Fagard, K. Pardaens, J. Vanhaecke // J. Hypertens. -1999. - Vol. 17 (12). - P. 1977-1981.

31. Association of blood pressure and heart rate response during exercise with cardiovascular events in the
Heart and Soul Study/M. R. Habibzadeh, Farzaneh- R. Far, P.Sarna [et al.] // J. Hypertens. -2010. - Vol. 28 (11). - P. 2236-2242.

32. The rate-pressure product as an index of myocardial oxygen consumption during exercise in patients with angina pectoris / F. L. Gobel, L. A. Norstrom, R. R. Nelson [et al.] // Circulation. - 1978. - Vol. 57 (3). - P. 549-556.

33. White W. B. Effects of graded-release diltiazem versus ramipril, dosed at bedtime, on early morning blood pressure, heart rate, and rate-pressure product / W. B. White, Y. Lacourciere, T. Gana // Am. Heart. J. - 2004. Vol. 148 (4). - P. 628-634.

34. Predictive value for mortality of the double product at rest obtained by home blood pressure measurement: the Ohasama study / R. Inoue, T. Ohkubo, M. Kikuya [et al.] // Am. J. Hypertens. - 2012. - Vol. 25 (5). - P. 568-575.

35. Sadrzadeh Rafie A. H. Age and double product (systolic blood pressure $\mathrm{x}$ heart rate) reserve-adjusted modification of the Duke Treadmill Score nomogram in men / A. H. Sadrzadeh Rafie, F. E. Dewey, G. W. Sungar// Am. J. Cardiol. - 2008. - Vol. 102 (10). - P. 1407-1412.

36. Rawles J. M. What is meant by a "controlled» ventricular rate in atrial fibrillation? / J. M. Rawles // Br. Heart J. - 1990. - Vol. 63 (3). - P. 157-161.

37. Bangalore S. Comparison of heart rate reserve versus $85 \%$ of age-predicted maximum heart rate as a measure of chronotropic response in patients undergoing dobutamine stress echocardiography / S. Bangalore, S. S. Yao, F. A. Chaudhry // Am. J. Cardiol. - 2006. - Vol. 97 (5). P. 742-747.

38. Comparison of the chronotropic response to exercise and heart rate recovery in predicting cardiovascular mortality / J. Myers, S. Y. Tan, J. Abella [et al.] // Eur. J. Prev. Cardiol. - 2007. - Vol. 14 (2). - P. 215-221.

39. Impaired heart rate recovery and chronotropic incompetence in patients with heart failure with preserved ejection fraction / T. T. Phan, G. N. Shivu, K. Abozguia [et al.] // Circ. Heart. Fail. - 2010. - Vol. 3 (1). - P. 29-34.

40. Relationship of exercise capacity and left ventricular dimensions in patients with a normal ejection fraction. An exploratory study / M. Meyer, R. K. McEntee, I. Nyotowidjojo [et al.] // PLoS One. - 2015. - Vol. 10 (3). - E0119432.

41. Schmid J. P. Chronotropic incompetence predicts impaired response to exercise training in heart failure patients with sinus rhythm / J. P. Schmid, M. Zurek, H. Saner // Eur. J. Prev. Cardiol. - 2013. - Vol. 20 (4). - P. 585-592.

42. Chronotropic incompentence and functional capacity in chronic heart failure: no role of $\beta$-blockers and $\beta$-blocker dose / D. Magrì, P. Palermo, F. M. Cauti [et al.] // Cardiovasc. Ther. - 2012. - Vol. 30 (2). - P. 100-108.

43. Association between resting heart rate, chronotropic index, and long-term outcomes in patients with heart failure receiving $\beta$-blocker therapy: data from the HF-ACTION trial / D. Dobre, F. Zannad, S. J. Keteyian [et al.] // Eur. Heart. J. - 2013. - Vol. 34 (29). - P. 2271-2280. 
Огляди літератури, оригінальні дослідження, погляд на проблему

\section{REFERENCES}

1. Zoni-Berisso, M., Lercari, F., Carazza, T., \& Domenicucci, S. (2014). Epidemiology of atrial fibrillation: European Perspective. Clinical Epidemiology, 6, 213-220. doi:10.2147/CLEP.S47385

2. Murin, J., Naditch-Brûlé, L., Brette, S., Chiang, C. E., O'Neill, J., \& Steg, P. G. (2014). Clinical characteristics, management, and control of permanent vs. nonpermanent atrial fibrillation: insights from the RealiseAF survey. PLoS One, 9(1), E86443. doi:10.1371/journal.pone.0086443

3. Chiang, C.E., Naditch-Brûlé, L., Murin, J., Goethals, M., Inoue, H., O'Neill, J., ... Steg, P.G. (2012). Distribution and risk profile of paroxysmal, persistent, and permanent atrial fibrillation in routine clinical practice: insight from the real-life global survey evaluating patients with atrial fibrillation international registry. Circulation: Arrhythmia and Electrophysiology, 5(4), 632-639. doi:10.1161/CIRCEP.112.970749

4. Steinberg, B.A., Kim, S., Thomas, L., Fonarow, G.C. Gersh, B.J., Holmqvist, F., . . . Piccini, J.P. (2015). Increased heart rate is associated with higher mortality in patients with atrial fibrillation (AF): results from the outcomes registry for better informed treatment of AF (ORBIT-AF). Journal of the American Heart Association, 4(9), E002031. doi:10.1161/JAHA.115.002031

5. Kirchhof, P., Benussi, S., Kotecha, D., Ahlsson, A., Atar, D., Casadei, B., . . . Zeppenfeld, K. (2016). ESC Guidelines for the management of atrial fibrillation developed in collaboration with EACTS. European Heart Journal, 37(38), 2893-2962. doi:10.1093/eurheartj/ehw210

6. Ponikowski, P., Voors, A.A., Anker, S.D., Bueno, H. Cleland, J.G., Coats, A. J., . . . Zamorano, J.L. (2016). 2016 ESC Guidelines for the diagnosis and treatment of acute and chronic heart failure. European Heart Journal, 37 (27), 2129-2200. doi:10.1093/eurheartj/ehw128

7. Mulder, B.A., Veldhuisen, D.J., Van, Crijns, H.J., Tijssen, J.G., Hillege, H. L., Alings, M., . . Gelder, I.C., Van. (2013). Lenient vs. strict rate control in patients with atrial fibrillation and heart failure: a post-hoc analysis of the RACE II study. European Journal of Heart Failure, 15 (11), 1311-1318. doi:10.1093/eurjhf/hft093

8. Gelder, I.C., Van, Groenveld, H.F., Crijns, H.J., Tuininga, Y.S., Tijssen, J. G., Alings, A.M., ... Berg, M.P., Van Den. (2010). Lenient versus Strict Rate Control in Patients with Atrial Fibrillation. The New England Journal of Medicine, 362, 1363-1373. doi:10.1056/NEJMoa1001337

9. Jaber, J., Cirenza, C., Jaber, J., Amaral, A., Almeida Sousa, J.M., De, Oliveira Filho, J.A., \& Paola, A.A., De. (2010). Influence of heart rate on quality of life in patients with chronic atrial fibrillation. Clinical Cardiology, 33 (4), E28-E32. doi:10.1002/clc.20528

10. Kato, Y., Suzuki, S., Uejima, T., Semba, H., Nagayama, O., Hayama, E., \& Yamashita, T. (2016). The relationship between resting heart rate and peak VO2: A comparison of atrial fibrillation and sinus rhythm. European Journal of Preventive Cardiology, 23 (13), 1429-1436. doi:10.1177/ 2047487316633885

11. Gelder, I.C., Van, Wyse, D.G., Chandler, M.L., Cooper, H.A., Olshansky, B., Hagens, V.E., \& Crijns, H.J. (2006). Does intensity of rate-control influence outcome in atrial fibrillation? An analysis of pooled data from the RACE and AFFIRM studies. Europace, 8(11), 935-942. doi:10.1093/europace/eul106
12. Zakeri, R., Borlaug, B.A., McNulty, S.E., Mohammed, S.F., Lewis, G.D., Semigran, M.J., . . . Redfield, M.M. (2014). Impact of atrial fibrillation on exercise capacity in heart failure with preserved ejection fraction: a RELAX trial ancillary study. Circulation: Heart Failure, 7 (1), 123130. doi:10.1161/CIRCHEARTFAILURE.113.000568

13. Atwood, J. E., Myers, J., Sullivan, M., Forbes, S., Friis, R., Pewen, W., ... Froelicher, V. (1988). Maximal exercise testing and gas exchange in patients with chronic atrial fibrillation. Journal of the American College of Cardiology, 11 (3), 508-513. doi:10.1016/0735-1097(88)91524-0

14. Atwood, J.E., Sullivan, M., Forbes, S., Myers, J., Pewen, W., Olson, H.G., \& Froelicher, V.F. (1987). Effect of beta-adrenergic blockade on exercise performance in patients with chronic atrial fibrillation. Journal of the American College of Cardiology, 10 (2), 314-320. doi:10.1016/ S0735-1097(87)80013-X

15. Anselmino, M., Scarsoglio, S., Saglietto, A., Gaita, F., \& Ridolfi, L. (2017). A computational study on the relation between resting heart rate and atrial fibrillation hemodynamics under exercise. PLoS One, 12 (1), E0169967. doi:10.1371/journal.pone.0169967

16. Schryver, N., De, Scavée, C., Marchandise, S., Pasquet, A., Meester, C., De, \& Le Polain De Waroux, J.B. (2014). Predictive value of the heart rate reserve in patients with permanent atrial fibrillation treated according to a strict rate-control strategy. Europace, 16 (8), 11251130. doi:10.1093/europace/euu033

17. Zharinov, O.Y., Kuts, V.O., \& Tkhor, N.V. (2006). Navantazhuvalni proby $v$ kardiolohii. Navchalnyi posibnyk [Exercise testing in cardiology. Tutorial]. Kyiv: Medytsyna svitu [in Ukrainian].

18. Gillis, A.M., Verma, A., Talajic, M., Nattel, S., \& Dorian, P. (2011). Canadian Cardiovascular Society atrial fibrillation guidelines 2010: rate and rhythm management. Canadian Journal of Cardiology, $27(1)$, 47-59. doi:10.1016/j. cjca.2010.11.001

19. Fletcher, G.F., Ades, P.A., Kligfield, P., Arena, R., Balady, G.J., Bittner, V. A., . . Williams, M.A. (2013). American Heart Association Exercise, Cardiac Rehabilitation, and Prevention Committee of the Council on Clinical Cardiology, Council on Nutrition, Physical Activity and Metabolism, Council on Cardiovascular and Stroke Nursing, and Council on Epidemiology and Prevention. Exercise standards for testing and training: a scientific statement from the American Heart Association. Circulation, 128 (8), 873-934. doi:10.1161/CIR.0b013e31829b5b44

20. Gulati, M., Shaw, L. J., Thisted, R.A., Black, H.R., Bairey Merz, C.N., \& Arnsdorf, M.F. (2010). Heart rate response to exercise stress testing in asymptomatic women: the st. James women take heart project. Circulation, 122 (2), 130137. doi:10.1161/CIRCULATIONAHA.110.939249

21. Rexhepi, M., \& Brestovci, B. (2014). Prediction of VO${ }_{2}$ max based on age, body mass, and resting heart rate. Human Movement, 15 (1), 56-59. doi:10.2478/humo-2014-0003

22. Fletcher, G.F., Balady, G.J., Amsterdam, E.A., Chaitman, B., Eckel, R., Fleg, J., ... Bazzarre, T. (2001). Exercise standards for testing and training: a statement for healthcare professionals from the American Heart Association. Circulation, 104 (14), 1694-1740. doi:10.1161/ hc3901.095960 
Огляди літератури, оригінальні дослідження, погляд на проблему

23. Aronov, D.M., \& Lupanov, V.P. (2002). Funktsionalnye proby $v$ kardiologii [Functional testing in cardiology]. Moscow: Medpress-inform [in Russian].

24. Khan, M.N., Pothier, C.E., \& Laver, M.S. (2005). Chronotropic incompetence as a predictor of death among patients with normal electrograms taking beta blockers (metoprolol or atenolol). The American Journal of Cardiology, 96 (9), 1328-1333. doi:10.1016/j.amjcard.2005.06.082

25. Sadrzadeh Rafie, A.H., Sungar, G.W., Dewey, F.E., Hadley, D., Myers, J., \& Froelicher, V.F. (2008). Prognostic value of double product reserve. European Journal of Preventive Cardiology, 15 (5), 541-547. doi:10.1097/ HJR.0b013e328305deef

26. Crapo, R.O., Casaburi, R., Coates, A.L., Enright, P.L., Maclntyre, N.R., McKay, R.T., . . Mottram, C. (2002). ATS statement: guidelines for the six-minute walk test. American Journal of Respiratory and Critical Care Medicine, 166 (1), 111-117. doi:10.1164/ajrccm.166.1.at1102

27. Enright, P.L., \& Sherrill, D.L. (1998). Reference equations for the six-minute walk in healthy adults. American Journal of Respiratory and Critical Care Medicine, 158 (5), 1384-1387. doi:10.1164/ajrccm.158.5.9710086

28. Nishiyama, Y., Morita, H., Harada, H., Katoh, A., Adachi, H., Koga, Y., \& Ikeda, H. (2010). Systolic blood pressure response to exercise as a predictor of mortality in patients with chronic heart failure. International Heart Journal, 51 (2), 111-115. doi:10.1536/ihj.51.111

29. Osada, N., Chaitman, B.R., Miller, L.W., Yip, D., Cishek, M.B., Wolford, T.L., \& Donohue, T.J. (1998). Cardiopulmonary exercise testing identifies low risk patients with heart failure and severely impaired exercise capacity for heart transplantation. Journal of the American College of Cardiology, 31 (3), 577-582. doi:10.1016/S07351097(97)00533-0

30. Fagard, R., Pardaens, K., \& Vanhaecke, J. (1999). Prognostic significance of exercise versus resting blood pressure in patients with chronic heart failure. Journal of Hypertension, 17 (12), 1977-1981. doi:10.1161/01.HYP.17.4.574

31. Habibzadeh, M.R., Farzaneh-Far, R., Sarna, P., Na, B., Schiller, N.B., \& Whooley, M.A. (2010). Association of blood pressure and heart rate response during exercise with cardiovascular events in the Heart and Soul Study. Journal of Hypertension, 28 (11), 2236-2242. doi:10.1097/ HJH.0b013e32833d455b

32. Gobel, F.L., Norstrom, L.A., Nelson, R.R., Jorgensen, C.R., \& Wang, Y. (1978). The rate-pressure product as an index of myocardial oxygen consumption during exercise in patients with angina pectoris. Circulation, 57 (3), 549-556. doi:10.1161/01.CIR.57.3.549

33. White, W.B., Lacourciere, Y., Gana, T., Pascual, M.G., Smith, D.H., \& Albert, K.S. (2004). Effects of gradedrelease diltiazem versus ramipril, dosed at bedtime, on early morning blood pressure, heart rate, and rate-pressure product. American Heart Journal, 148 (4), 628-634. doi:10.1016/j.ahj.2004.07.008
34. Inoue, R., Ohkubo, T., Kikuya, M., Metoki, H., Asayama, K., Kanno, A., ... Imai, Y. (2012). Predictive value for mortality of the double product at rest obtained by home blood pressure measurement: the Ohasama study. The American Journal of Hypertension, 25 (5), 568-575. doi:10.1038/ajh.2012.3

35. Sadrzadeh Rafie , A.H., Dewey, F.E., Sungar, G.W., Ashley, E.A., Hadley, D., Myers, J., \& Froelicher, V.F. (2008). Age and double product (systolic blood pressure $\mathrm{x}$ heart rate) reserve-adjusted modification of the Duke Treadmill Score nomogram in men. The American Journal of Cardiology, 102 (10), 1407-1412. doi:doi:10.1016/j.amjcard.2008.07.020

36. Rawles, J.M. (1990). What is meant by a «controlled» ventricular rate in atrial fibrillation? British Heart Journal, 63 (3), 157-161. doi:10.1136/hrt.63.3.157

37. Bangalore, S., Yao, S.S., \& Chaudhry, F.A. (2006). Comparison of heart rate reserve versus $85 \%$ of age-predicted maximum heart rate as a measure of chronotropic response in patients undergoing dobutamine stress echocardiography. The American Journal of Cardiology, 97 (5), 742-747. doi:10.1016/j.amjcard.2005.09.111

38. Myers, J., Tan, S.Y., Abella, J., Aleti, V., \& Froelicher, V.F. (2007). Comparison of the chronotropic response to exercise and heart rate recovery in predicting cardiovascular mortality. European Journal of Preventive Cardiology, 14 (2), 215-221. doi:10.1097/HJR.0b013e328088cb92

39. Phan, T.T., Shivu, G.N., Abozguia, K., Davies, C., Nassimizadeh, M., Jimenez, D., . . Frenneaux, M. (2010). Impaired heart rate recovery and chronotropic incompetence in patients with heart failure with preserved ejection fraction. Circulation: Heart Failure, 3 (1), 29-34. doi:10.1161/CIRCHEARTFAILURE.109.877720

40. Meyer, M., McEntee, R.K., Nyotowidjojo, I., Chu, G. \& LeWinter, M.M. (2015). Relationship of exercise capacity and left ventricular dimensions in patients with a normal ejection fraction. An exploratory study. PLoS One, 10 (3), E0119432. doi:10.1371/journal.pone.0119432

41. Schmid, J.P., Zurek, M., \& Saner, H. (2013). Chronotropic incompetence predicts impaired response to exercise training in heart failure patients with sinus rhythm. European Journal of Preventive Cardiology, 20 (4), 585-592. doi:10.1177/2047487312444368

42. Magrì, D., Palermo, P., Cauti, F.M., Contini, M., Farina, S., Cattadori, G., . . . Agostoni, P. (2012). Chronotropic incompentence and functional capacity in chronic heart failure: no role of $\beta$-blockers and $\beta$-blocker dose. Cardiovascular Therapy, 30 (2), 100-108. doi:10.1111/j.1755-5922.2010.00184.x

43. Dobre, D., Zannad, F., Keteyian, S.J., Stevens, S.R., Rossignol, P., Kitzman, D.W., . . E Ellis, S.J. (2013). Association between resting heart rate, chronotropic index, and long-term outcomes in patients with heart failure receiving B-blocker therapy: data from the HF-ACTION trial. European Heart Journal, 34 (29), 2271-2280. doi:10.1093/eurheartj/ehs433 


\title{
Огляди літератури, оригінальні дослідження, погляд на проблему \\ ВЛИЯНИЕ ЧАСТОТЫ СЕРДЕЧНЫХ СОКРАЩЕНИЙ НА ТОЛЕРАНТНОСТЬ К ФИЗИЧЕСКИМ НАГРУЗКАМ У ПАЦИЕНТОВ С ПОСТОЯННОЙ ФОРМОЙ ФИБРИЛЛЯЦИИ ПРЕДСЕРДИЙ НЕКЛАПАННОГО ПРОИСХОЖДЕНИЯ
}

\author{
๑о. С. Сычёв 1, П. Б. Романюк', О. В. Срибная', В. Г. Гурьянов
}

${ }^{1}$ Государственное учреждение «Национальный научный центр «Институт кардиологии имени академика М. Д. Стражеско» Национальной академии медицинских наук Украины», Киев ${ }^{2}$ Национальный медицинский университет имени А. А. Богомольца, Киев

РЕЗЮМЕ. Цель исследования - оценить динамические изменения толерантности к физическим нагрузкам у пациентов с постоянной формой фибрилляции предсердий неклапанного происхождения на фоне применения $\beta$-адреноблокаторов (ББ), определить критическое значение ЧСС, как предиктор негативной динамики функционального состояния пациентов при 6-месячном наблюдении, выявить преимущество одной из стратегий контроля ЧСС.

Материал и методы. В исследование последовательно включены 30 пациентов. Длительность наблюдения составила $(238,3 \pm 17,0)$ дней, дизайн предусматривал 3 визита. Титрование дозы ББ проводилось $(67,7 \pm 10,3)$ дней (интервал между 1 и 2 визитами). Прием максимальной или максимально переносимой дозы ББ длился $(170,6 \pm 17,7)$ дней (интервал между 2 и 3 визитами). Парные нагрузочные пробы - тредмил-тест (ТT) и тест 6-минутной ходьбы (6МТX) проводились во время 2 и 3 визитов.

Результаты. В течение 6-месячного наблюдения в обследованной группе пациентов значимо выросли САД на фоне субмаксимальной ФН, инотропный резерв и резерв двойного произведения (ДП), а также уменьшился индекс ДП. Проведенный корреляционный анализ выявил связь индекса ДП с показателем среднесуточной чСС по данным 24-часового ХМ ЭКГ. При достижении жесткого контроля чСС через 6 месяцев значимо уменьшилось расстояние, пройденное пациентами при 6МТХ. При сопоставлении обеих стратегий жесткий контроль показал значимое преимущество по снижению ЧСС покоя, ЧСС на фоне субмаксимальной ФН (2 и 3 визиты), ДП покоя, индекса ДП, а также повышение хронотропного резерва (2 визит).

Выводы. Через 6 месяцев при применении ББ у больных ПФФП неклапанного происхождения отмечается улучшение толерантности к ФН. Предиктором ее снижения является среднесуточная ЧСС >90,5 уд/мин, зафиксированная во время ХМ ЭКГ. Жесткий контроль ЧСС имеет преимущество перед мягким по улучшению функционального состояния пациентов и их прогноза.

КЛЮчЕВЫЕ СЛОВА: постоянная форма фибрилляции предсердий; контроль частоты сердечных сокращений; толерантность к физическим нагрузкам; тредмил-тест; тест 6-минутной ходьбы.

\section{INFLUENCE OF THE HEART RATE ON THE EXERCISE CAPACITY IN PATIENTS WITH A PERMANENT ATRIAL FIBRILLATION NON-VALVULAR ETIOLOGY}

\author{
๑O. S. Sychov', P. B. Romaniuk', O. V. Sribna', V. H. Hurianov² \\ ${ }^{1}$ National Scientific Center «M. Strazhesko Institute of Cardiology of NAMS of Ukraine», Kyiv \\ ${ }^{2}$ O. Bohomolets National Medical University, Kyiv
}

SUMMARY. The aim of the study - to estimate the dynamic changes of exercise capacity in patients with permanent atrial fibrillation non-valvular etiology during treatment with $\beta$-blockers (BB), determination the critical value of the heart rate as a negative dynamic predictor of the patients functional state during 6 month monitoring, identification the preference for one of the HR control strategies.

Materials and Methods. 30 patients were included in this study. The duration of observation was (238.3 \pm 17.0$)$ days, the design consisted in 3 visits. Titration of the BB dose lasted (67.7 \pm 10.3$)$ days (the interval between 1 and 2 visits).

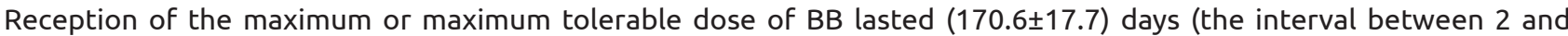
3 visits). Paired exercise testing - treadmill test (TT) test and 6-minute walk test (6MWT) were performed during 2 and 3 visits.

Results. During follow-up period significantly increased submaximal systolic blood pressure, inotropic reserve, reserve double product (DP) and reduced DP index. The performed correlation analysis revealed a relationship between the DP index with the mean daily HR value according to 24 h Holter ECG. With strict heart rate control after 6 months significantly decreased the 6MWT distance. When comparing both strategies strict control showed a significant advantage for reducing resting heart rate, heart rate at submaximal exercise testing (visits 2 and 3), resting DP, DP index, as well as increased chronotropic reserve (2 visit).

Conclusions. There was an improvement in exercise capacity after 6 months with the treatment of BB in patients with PAF non-valvular etiology. Predictor of its decrease is the median daily heart rate $>90.5$ beats/min, recorded during the Holter ECG. Strict heart rate control has an advantage over lenient on improving the patients functional state and their outcomes.

KEY WORDS: permanent atrial fibrillation; heart rate control; exercise capacity; treadmill test; 6-minute walk test. 